\title{
HUBUNGAN KEBIASAAN MEROKOK DENGAN GANGGUAN POLA TIDUR PADA REMAJA
}

\author{
Budi Kristanto $^{1}$, Ahmad Sarif ${ }^{2}$
}

\begin{abstract}
For some people, smoking has become a necessity of life that can not be abandoned in everyday life - the day. Results Health Research in 2013, the smoking behavior of population aged 15 years and over or adolescence is still a decline from 2007 to 2013, is likely to increase from $34.2 \%$ in 2007 to $36.2 \%$ in 2013 .

This research uses correlation study with cross sectional approach to determine the relationship of smoking as an independent variable with disruption of sleep patterns in adolescents as the dependent variable. The population in this study were all adult smokers in the village of Wangkah Gedangan Grogol, Sukoharjo, ie a total of 30 adolescent smokers. Researchers using a questionnaire with questions about the amount to 3 point for an overview of smoking and 10 of the questions for the description of sleep disorders. The data obtained then tabulated tabulation and analyzed using SPSS 16 for Windows.

Research result: 1) From the results of this study can be obtained that the majority of respondents, a number of $15(50 \%)$ to the category of light smokers, while 9 respondents $(30 \%)$ to the category of moderate smokers, and 6 respondents $(20 \%)$ categories of heavy smokers. 2) The majority of respondents with moderate sleep disorder category, the number of 24 respondents $(80 \%)$, while 4 respondents $(13.3 \%)$ with mild sleep disorder category, and 2 respondents $(6.7 \%)$ with severe sleep disorder category. Of all respondents were 30 teenage $100 \%$ impaired sleep patterns. 3) Pearson Chi-Square 5.513889 , where <of $\alpha: 0: 05$. It can be concluded that there is no relationship between smoking category by category disruption of sleep patterns. Linear or non smoking category to the category of sleep disorders.
\end{abstract}

Keywords: Smoking, disruption of sleep patterns, teen age

\section{PENDAHULUAN}

Pada zaman modern saat ini, rokok bukanlah benda yang asing. Bagi mereka yang hidup di desa maupun di kota umumnya mereka sudah mengenal benda yang bernama rokok. Bahkan sebagian orang, rokok sudah menjadi kebutuhan hidup yang tidak bisa ditinggalkan begitu saja dalam kehidupan seharihari (Jaya, 2009). Sedangkan menurut Husaini (2006), merokok adalah suatu kebiasaan (habituation) dan bukan suatu ketergantungan (addiction). Kebiasaan adalah membiasakan diri melakukan suatu karena ada bahan, bila ia menghentikan kebiasaannya, maka akan muncul gejala - gejala psikis dari dalam dirinya. Sedangkan ketergantungan adalah sebagaimana ketergantungan heroin ataupun kokain adalah ketergantungan fisik dan psikis.

Hasil Riset Kesehatan Dasar tahun 2013, perilaku merokok penduduk usia 15 tahun ke atas atau usia remaja masih belum terjadi penurunan dari 2007 ke 2013, cenderung meningkat dari $34.2 \%$ pada 2007 menjadi $36.2 \%$ pada tahun 2013. 64.9\% laki - laki dan $2.1 \%$ perempuan masih menghisap rokok tahun 2013. Ditemukan bahwa $1.4 \%$ perokok masih berumur 10 - 14 tahun, 9.9\% perokok pada kelompok tidak bekerja dan $32.3 \%$ pada kelompok batas interval kepemilikan terendah. Sedangkan rerata jumlah batang rokok yang dihisap adalah sekitar 12 batang. 
Bervariasi dari yang terendah 10 batang di Daerah Istimewa Yogyakarta (DIY) dan tertinggi di Bangka Belitung 18.3 batang. (Badan Penelitian dan Pengembangan Kesehatan Kementerian Kesehatan RI, 2013) Menurut Jaya (2009), merokok dapat menyebabkan antibodi menurun, kanker paru, penuaan, tumor, plak arteri, kanker kulit, kanker kandung kemih, pikun, dan kebutaan. Sedangkan menurut Husaini (2006), penyakit yang diakibatkan oleh merokok antara lain, infeksi saluran pernafasan, emphysema, alergi, hipertensi, bronchitis, penyakit jantung koroner, infeksi lidah dan rongga mulut, berbagai masalah kehamilan, infeksi pada lambung, mengentalnya aliran darah, sariawan, obstruksi jalan nafas kronik, infeksi tenggorokan dan terganggunya pita suara, sakit mata, sakit pada system pencernaan, kecemasan, pusing, menggigil, meningkatnya detak jantung, sakit pada dada, asma, melemahnya aktivitas peredaran darah, berkurangnya energy dan vitalitas, meningkatnya keasaman pada lambung, melemahnya kemampuan dalam merasakan rasa pada makanan di lidah dan melemahnya kemampuan penciuman pada hidung, lemahnya kemampuan seksual, impotensi, insomnia, influenza dan kanker.

Dari paparan Husaini (2006), menyebutkan salah satu masalah yang dapat timbul pada perokok adalah insomnia atau gangguan tidur. Menurut Mubarak dan Chayatin (2007), tidur adalah suatu perubahan kesadaran ketika presapsi dan reaksi individu terhadap lingkungan menurun. Tidur dikarakteristikkan dengan aktivitas fisik yang minimal, tingkat kesadaran yang bervariasi, perubahan proses fisiologis tubuh, dan penurunan respon terhadap stimulus eksternal. Hampir sepertiga dari waktu kita, kita gunakan untuk tidur. Pola tidur normal pada remaja \pm 7 - 8 jam/hari. Sedangkan menurut Kozier, et al., (2010), tidur merupakan kebutuhan dasar manusia dan sebuah proses biologis yang umum pada semua orang. Ditinjau dari sejarahnya, tidur dianggap sebagai keadaan tidak sadar. Baru - baru ini, tidur telah dianggap sebagai perubahan status kesadaran yang di dalamnya presepsi dan reaksi individu terhadap lingkungannya mengalami penurunan. Pada umumnya tidur juga bisa mengalami gangguan seperti insomnia, parasomnia, hipersomnia, narkolepsi, dan apnea tidur. Menurut Mubarak dan Chayatin (2007), banyak faktor yang mempengaruhi kualitas maupun kuantitas tidur, diantaranya adalah faktor penyakit, lingkungan, kelelahan, gaya hidup, stress emosional, stimulan dan alkohol, diet, merokok, medikasi, dan motivasi.

Berdasarkan hasil penelitian yang dilakukan oleh Vaora (2014), yang berjudul "Hubungan antara Kebiasaan Merokok Usia Remaja dengan Gangguan Pola Tidur". didapatkan data bahwa sebagian besar siswa mengkonsumsi rokok dengan kategori perokok ringan yakni sebanyak 34 responden $(42 \%)$ dan mayoritas responden mengalami insomnia yakni sebanyak 69 responden (85.2\%). Hasil analisis statistik menunjukkan bahwa terdapat hubungan antara kebiasaan merokok remaja dengan gangguan pola tidur dengan pengaruh bermakna yakni $p$ value $=$ 0.005 .

Dari studi pendahuluan yang peneliti lakukan di Desa Wangkah, yaitu salah satu desa yang berada di Kelurahan Gedangan Kecamatan Grogol Kabupaten Sokoharjo. Ada sekitar 30 remaja yang merokok. Dari hasil wawancara 5 orang remaja yang merokok, 3 orang 
mengatakan tidak mengalami gangguan tidur seperti sering terbangun di malam hari, tapi tidur sering lebih dari jam 12 malam. Sedangkan 2 orang yang lain mengatakan sering terbangun dimalam hari karena sering batuk batuk. Dari hasil wawancara 5 orang remaja yang tidak merokok, semua mengatakan tidak mengalami gangguan tidur seperti sering terbangun di malam hari dan tidur larut malam.

Terkait permasalahan di atas, maka peneliti tertarik melakukan penelitian tentang "Hubungan Kebiasaan Merokok dengan Gangguan Pola Tidur pada Remaja“.

\section{TUJUAN PENELITIAN}

Tujuan umum penelitian ini untuk mengetahui hubungan antara kebiasaan merokok dengan gangguan pola tidur pada remaja, dan secara khusus untuk mengetahui gambaran kebiasaan merokok pada remaja dan deskripsi gangguan tidur pada remaja

\section{METODE/DESAIN PENELITIAN}

Penelitian ini merupakan jenis penelitian korelasi dengan pendekatan cross sectional untuk mengetahui hubungan kebiasaan merokok sebagai variabel bebas dengan gangguan pola tidur pada remaja sebagai variabel terikat.

\section{POPULASI, SAMPEL, DAN TEHNIK SAMPLING}

Populasi pada penelitian ini adalah seluruh remaja perokok di Desa Wangkah Gedangan Grogol Sukoharjo, yaitu sejumlah 30 remaja perokok. Dikarenakan jumlah populasi tidak terlalu banyak maka pada penelitian mengambil seluruh populasi sebagai sampel atau responden. Metode penarikan sampel yang digunakan adalah sampling jenuh yaitu seluruh remaja perokok di Desa Wangkah
Gedangan Grogol Sukoharjo pada saat dilakukan penelitian.

\section{HASIL PENELITIAN}

1. Distribusi frekuensi

Tabel 1.

Distribusi Frekuensi Kategori

Merokok Berdasarkan Jumlah yang Dihisap dalam Sehari

\begin{tabular}{lcc}
\hline Kategori & $f$ & $\%$ \\
\hline $\begin{array}{l}\text { Ringan } \\
(2-8 \text { batang/hari) }\end{array}$ & 15 & 50 \\
$\begin{array}{l}\text { Sedang } \\
\text { (9-15 batang/hari) }\end{array}$ & 9 & 30 \\
$\begin{array}{l}\text { Berat } \\
(>15 \text { batang/hari) }\end{array}$ & 6 & 20 \\
\hline Jumlah & 30 & 100 \\
\hline
\end{tabular}

Dari tabel di atas dapat diketahui bahwa mayoritas responden yaitu sejumlah 15 (50\%) dengan kategori perokok ringan, sedangkan 9 responden (30\%) dengan kategori perokok sedang, dan 6 responden $(20 \%)$ kategori perokok berat.

Tabel 2.

Distribusi Frekuensi Gangguan Tidur

\begin{tabular}{lcc}
\multicolumn{3}{c}{ Gangguan Tidur } \\
\hline $\begin{array}{l}\text { Kategori } \\
\text { Gangguan }\end{array}$ & $f$ & $\%$ \\
Tidur & & \\
\hline Ringan & 4 & 13.3 \\
Sedang & 24 & 80 \\
Berat & 2 & 6.7 \\
\hline Jumlah & 30 & 100 \\
\hline
\end{tabular}

Dari tabel di atas terlihat bahwa mayoritas responden dengan kategori gangguan tidur sedang, yaitu sejumlah 24 responden (80\%), sedangkan 4 responden (13.3\%) dengan kategori gangguan tidur ringan, dan 2 responden (6.7\%) dengan kategori gangguan tidur berat. 
2. Hasil Analisa

a. Tabulasi Silang

Tabel 3.

Tabulasi Silang Kategori

Merokok dengan Kategori Gangguan tidur

\begin{tabular}{lccc}
\hline & \multicolumn{3}{c}{ Gangguan Tidur } \\
\cline { 2 - 4 } Merokok & Ringan & Sedang & Berat \\
\hline Ringan & 1 & 14 & 0 \\
Sedang & 1 & 7 & 1 \\
Berat & 2 & 3 & 1 \\
\hline Total & 4 & 24 & 2 \\
\hline
\end{tabular}

b. Hasil Uji Korelasi dengan Chi Square

Tabel 4.

Hasil Uji Korelasi

\begin{tabular}{lcc} 
& $p$ & Df \\
& Value & \\
\hline Pearson & 5.513889 & 4 \\
Chi-Square & & \\
Likelihood Ratio & 5.870263 & 4 \\
N of Valid Cases & 30 & \\
\hline
\end{tabular}

Dari data di atas dapat di interpretasikan :

1) Hipotesis : ada hubungan antara kategori merokok dengan kategori gangguan pola tidur

2) Dengan melihat data di atas, didapatkan bahwa Pearson Chi-Square 5.513889, dimana $>$ dari $\alpha$ : 0.05 .

3) Maka dapat disimpulkan bahwa tidak ada hubungan antara kategori merokok dengan kategori gangguan pola tidur.

\section{PEMBAHASAN}

1. Kebiasaan Merokok pada

Remaja

Menurut Purnamasari (2013), ada tiga tingkatan merokok, meliputi : perokok ringan apabila menghabiskan rokok sebanyak 2 - 8 batang perhari dalam waktu $\leq 30$ menit, rokok yang dihisap sampai habis lalu mengambil rokok yang baru, perokok sedang apabila menghabiskan rokok sebanyak 9 - 15 batang perhari dalam waktu 10 - 30 menit, rokok yang dihisap sampai habis lalu mengambil rokok yang baru, dan perokok berat apabila menghabiskan rokok $\geq 15$ batang perhari dalam waktu $5-10$ menit, rokok yang dihisap sampai habis lalu mengambil rokok yang baru.

Pada penelitian ini, dimana responden yang diteliti sebanyak 30 remaja, didapatkan hasil bahwa mayoritas responden yaitu sejumlah 15 responden $(50 \%)$ dengan kategori perokok ringan, sedangkan 9 responden $(30 \%)$ dengan kategori perokok sedang, dan 6 responden $(20 \%)$ kategori perokok berat.

Penelitian ini memang menunjukkan bahwa mayoritas responden masih kategori perokok ringan yaitu mengkonsumsi rokok antara 2-8 batang per hari, namun tidak menutup kemungkinan untuk terjadinya peningkatan pada masa yang akan datang. Hal tersebut sesuai dengan yang dipaparkan Caldwell (2009), nikotin dapat disamakan dengan narkotika, sebab dapat menimbulkan kecanduan. Bedanya adalah pecandu narkotika mampu bertoleransi sedangkan perokok tidak dapat beradaptasi dengan meningkatnya konsumsi merokok.

Informasi lain yang perlu diperhatikan dari hasil penelitian ini adalah $30 \%$ responden merupakan perokok sedang dan $20 \%$ yang lain adalah perokok berat. Rentang usia pada penelitian ini adalah 18-25 tahun yang merupakan masa produktif. Efek dari menghisap rokok dapat 
mengganggu kesehatan pada masa produktif ini.

Faktor penyebab merokok pada remaja cukup beragam, menurut Widiansyah (2014), meliputi : pengaruh orang tua, dimana remaja perokok adalah anak anak yang berasal dari rumah tangga yang tidak bahagia, dimana orang tua tidak begitu memperhatikan anak-anaknya, dibandingkan dengan remaja yang berasal dari lingkungan keluarga yang bahagia. Remaja yang berasal dari keluarga konservatif akan lebih sulit untuk terlibat dengan rokok maupun obat - obatan dibandingkan dengan keluarga yang permisif, dan yang paling kuat pengaruhnya adalah bila orang tua sendiri menjadi figur. Contoh yaitu perokok berat, maka anak anaknya akan mungkin sekali untuk mencontohnya. Perilaku merokok lebih banyak didapati pada mereka yang tinggal dengan satu orang tua (single parent), karena orang tua tidak terlalu memperhatikan anakanaknya.

Faktor yang lain adalah pengaruh teman, berbagai fakta mengungkapkan bahwa semakin banyak remaja merokok maka semakin besar kemungkinan teman - temannya adalah perokok juga dan demikian sebaliknya. Ada dua kemungkinan yang terjadi dari fakta tersebut, pertama remaja tersebut terpengaruh oleh teman - temannya atau sebaliknya. Sifat remaja pada umumnya selalu ingin tahu hal - hal yang baru, ingin menonjolkan diri, ingin mencari identitas diri, cenderung emosional.

Faktor yang lain yang menyebabkan remaja merokok adalah faktor kepribadian seperti diuraikan Widiansyah (2014), dimana kepribadian remaja mencoba untuk merokok karena alasan ingin tahu atau ingin melepaskan diri dari rasa sakit dan kebosanan. Satu sifat kepribadian yang bersifat pada pengguna obat-obatan (termasuk rokok) ialah konformitas sosial. Melihat iklan di media massa dan elektronik yang menampilkan gambaran bahwa perokok adalah lambang kejantanan atau glamour, membuat remaja seringkali terpicu untuk mengikuti perilaku seperti yang ada dalam iklan tersebut.

Pada penelitian ini memberikan gambaran dimana kategori remaja yang merokok cukup beragam, meliputi ringan, sedang dan berat. Menurut Caldwell (2009), setiap kali mengisap sebatang rokok, beresiko terpapar 45 jenis bahan kimia beracun. Sebenarnya terdapat lebih dari 200 unsur. Beberapa senyawa penting namun berbahaya adalah lutidin, rubidin, formalin, asam karbolik, metalimin, akreolin, colidin, viridian, arsen, asam fomik, nikotin, hydrogen sulfide, pirel, furfurol, benzopiren, metal alcohol, asam hidrosianik, korodin, ammonia, metana, karbon monoksida, dan piridin.

Menurut Jaya (2009), kandungan zat kimia dalam rokok, antara lain adalah tar. Tar adalah kumpulan dari beribu - ribu bahan kimia dalam komponen padat asap rokok dan bersifat karsinogen. Pada saat rokok dihisap, tar masuk ke dalam rongga mulut sebagai uap padat. Setelah dingin akan menjadi padat dan membentuk endapan berwarna coklat pada permukaan gigi, saluran pernafasan, dan paru - paru. Pengendapan ini bervariasi antara $3-40 \mathrm{mg}$ per batang, sementara kadar tar dalam rokok berkisar $24-45 \mathrm{mg}$. 
Tar menyebabkan batuk, sesak napas dan kanker jalan napas.

Zat yang lain adalah Nikotin yang dapat meracuni saraf tubuh, meningkatkan tekanan darah, menimbulkan penyempitan pembuluh darah tepi, jantung berdebar - debar, meningkatkan kadar kolesterol dalam darah serta menyebabkan ketagihan dan ketergantungan pada pemakainya. Kadar nikotin 4-6 mg yang di hisap oleh orang dewasa setiap hari sudah bisa membuat seseorang ketagihan.

Sebatang rokok menghasilkan $\mathrm{Pb}$ sebanyak 0.5 ug. Sebungkus rokok (isi 20 batang) yang habis dihisap dalam satu hari menghasilkan 10 ug $\mathrm{Pb}$. Sementara ambang batas timah hitam yang masuk ke dalam tubuh adalah 20 ug per hari.

Gas karbonmonoksida (CO), gas ini memiliki kecenderungan yang kuat untuk berikatan dengan hemoglobin dalam sel - sel darah merah. Seharusnya hemoglobin berikatan dengan oksigen untuk pernapasan sel - sel tubuh. Kadar gas $\mathrm{CO}$ dalam darah bukan perokok kurang dari $1 \%$. Sementara dalam darah perokok mencapai 4 - $15 \%$. Jadi gas karbonmonoksida mengikatkan hemoglobin, sehingga darah tidak mampu mengikatkan oksigen.

2. Gangguan Pola Tidur pada Remaja

Dari penelitian ini diperoleh informasi bahwa mayoritas responden dengan kategori gangguan tidur sedang, yaitu sejumlah 24 responden (80\%), sedangkan 4 responden (13.3\%) dengan kategori gangguan tidur ringan, dan 2 responden (6.7\%) dengan kategori gangguan tidur berat.

Pada penelitian ini semua responden berjumlah 30 remaja, keseluruhannya adalah perokok, yang dikategorikan menjadi perokok ringan, sedang dan berat. Dari seluruh responden $(100 \%)$ mengalami gangguan tidur. Hal tersebut sesuai dengan penelitian sebelumya yang dilakukan Vaora (2014), dimana didapatkan terdapat hubungan antara kebiasaan merokok remaja dengan gangguan pola tidur dengan pengaruh bermakna yakni $p$ value $=0.005$.

Secara teori dapat dijelaskan bahwa salah satu faktor yang dapat mempengaruhi kualitas dan kuantitas tidur adalah merokok, seperti diuraikan Kozier, et al. ( 2010), nikotin yang terkandung dalam rokok memiliki efek stimulasi pada tubuh. Akibatnya perokok sering kali kesulitan untuk tidur dan mudah terbangun dimalam hari.

Selain gangguan tidur menurut Caldwell (2009), nikotin dapat disamakan dengan narkotika, sebab dapat menimbulkan kecanduan. Bedanya adalah pecandu narkotika mampu bertoleransi sedangkan perokok tidak dapat beradaptasi dengan meningkatnya konsumsi merokok.

Menurut Caldwell (2009) bahaya dari merokok, meliputi : gangguan organ mulut, kanker, penyakit jantung, gangguan sirkulasi darah dan gangguan sistem pencernaan.

Merokok dapat menyebabkan batuk, kedua mata perih dan agak kering, tenggorokan terasa serak dan kasar. Setelah melewati tenggorokan, asap masuk paru menghasilkan panas mencapai $88^{\circ} \mathrm{C}$ yang merusak mulut, lidah, langit - langit, ujung dan pangkal tenggorokan. Panas menyebabkan iritasi di area tersebut kemudian berkembang menjadi kanker.

Kanker terjadi ketika sel yang tadinya normal akan tumbuh 
tanpa dikontrol oleh tubuh. Dan kemudian akan berkembang menjadi tumor yang mematikan dan menyebar dengan cepat ke bagian tubuh lain. Misalnya kanker paru, dalam rokok yang dapat menyebabkan kanker adalah tar.

Jantung merupakan organ yang memompa darah ke seluruh tubuh. Nikotin menyebabkan dinding pembuluh darah di seluruh tubuh menyempit maka jantung harus bekerja lebih keras dalam memompa darah. Nikotin juga menyebabkan ketidaknormalan sirkulasi darah. Jika suatu bagian tubuh mengalami gangguan sirkulasi darah, maka bagian tersebut tidak menerima pasokan nutrisi dan oksigen yang cukup untuk menjalankan fungsi normal dan mengakibatkan kerusakan jaringan, pembusukan dan diperlukan amputasi.

Gangguan yang lain adalah pada system peredaran darah Burger's disease adalah semacam alergi terhadap nikotin, menyerang sebelah tangan atau sebelah kaki dan banyak menyerang laki laki. Pada perempuan ganngguan ini dimakan reynaud's disease yang menyerang kedua tangan dan kedua kaki. Penderita umumnya mengeluh merasa dingin dan pucat pada area tubuh yang terserang.

Nikotin mengerutkan dan melukai pembuluh darah pada dinding lambung. Hal ini menyebabkan iritasi pada lambung dan menyebabkan asam lambung naik. Kelebihan asam lambung menyebabkan luka pada dinding lambung.

Dari uraian di atas menunjukkan cukup kompleksnya masalah kesehatan yang diakibatkan dari merokok. Pada penelitian ini fokus informasi yang dicari adalah pada gangguan tidur, masalah kesehatan yang lain tidak menjadi focus dalam penelitian ini.

3. Hubungan antara Kategori Merokok dengan Kategori Gangguan pola Tidur pada Remaja

Seperti diuraikan di atas, hubungan antara merokok dengan gangguan pola tidur telah dibuktikan pada penelitian sebelumnya. Pada penelitian ini fokus yang ingin di cari adalah hubungan antara kategori kebiasaan merokok dengan kategori gangguan pola tidur. Apakah kategori kebiasaan merokok tersebut berbanding lurus atau linier dengan gangguan pola tidur atau tidak.

Hasil uji statistik dengan Chi Square didapatkan bahwa Pearson Chi-Square 5.513889, dimana < dari $\alpha$ : 0.05. Maka dapat disimpulkan bahwa tidak ada hubungan antara kategori merokok dengan kategori gangguan pola tidur.

Hal tersebut memberikan makna bahwa kategori merokok tidak berbading lurus dengan beratnya gangguan tidur.

Pada penelitian ini perokok ringan sejumlah 15 responden, 1 responden mengalami gangguan tidur ringan dan 14 orang mengalami gangguan tidur sedang. Jumlah perokok sedang sejumlah 9 responden, 1 responden mengalami gangguan tidur ringan, 7 responden gangguan tidur sedang dan 1 responden dengan gangguan tidur berat. Jumlah perokok berat sejumlah 6 responden, 2 responden mengalami gangguan tidur ringan, 3 responden dengan gangguan tidur sedang dan sisanya 1 responden dengan gangguan tidur berat.

Dari tabulasi silang memberikan informasi bahwa mayoritas responden dengan kategori 
perokok ringan berjumlah 15 responden (50\%), mayoritas responden dengan kategori gangguan tidur sedang, yaitu sejumlah 24 responden (80\%).

Secara rasional apabila jumlah rokok yang dikonsumsi semakin banyak kadar zat yang terakumulasi di dalam tubuh akan semakin banyak dan tentu saja dampaknya akan lebih buruk, namun terkait dengan gangguan tidur hal tersebut tidak ditunjukkan dalam penelitian ini.

Hal tersebut cukup dapat dimengerti karena faktor yang berpengaruh terhadap gangguan tidur cukup banyak seperti dipaparkan oleh Kozier, et al. (2010), faktor yang mempengaruhi kuantitas dan kualitas tidur yaitu : penyakit, lingkungan, kelelahan, gaya hidup, stress emosional, stimulan dan alkohol, diet, merokok, medikasi dan motivasi.

Penyakit dapat menyebabkan nyeri atau distres fisik yang dapat menyebabkan gangguan tidur. Individu yang sakit membutuhkan waktu tidur yang lebih banyak dari pada biasanya. Faktor lingkungan dapat membantu sekaligus menghambat proses tidur. Tidak adanya stimulus tertentu atau adanya stimulus yang asing dapat menghambat upaya tidur.

Kondisi tubuh yang lelah dapat mempengaruhi pola tidur seseorang. Semakin lelah seseorang, semakin pendek siklus tidur REM yang dilaluinya. Individu yang sering berganti jam kerja harus mengatur aktivitasnya agar bisa tidur pada waktu yang tepat. Ansietas dan depresi sering kali mengganggu tidur seseorang. Kondisi ansietas dapat meningkatkan kadar norepinefrin darah melalui stimulasi sistem saraf simpatis.
Kafein yang terkandung dalam beberapa minuman dapat merangsang SSP (Susunan Saraf Pusat) sehingga dapat mengganggu pola tidur. Sedangkan konsumsi alkohol yang berlebihan dapat mengganggu siklus tidur REM. Ketika pengaruh alkohol telah hilang, individu sering kali mengalami mimpi buruk.

Penurunan berat badan dikaitkan dengan penurunan waktu tidur dan seringnya terjaga dimalam hari. Sebaliknya, penambahan berat badan dikaitkan dengan peningkatan total tidur dan sebaliknya periode terjaga dimalam hari. Nikotin yang terkandung dalam rokok memiliki efek stimulasi pada tubuh. Akibatnya perokok sering kali kesulitan untuk tidur dan mudah terbangun dimalam hari. Obat obatan tertentu dapat mempengaruhi kualitas tidur seseorang. Keinginan untuk tetap terjaga terkadang dapat menutupi perasaan lelah seseorang. Sebaliknya, perasaan bosan atau tidak adanya motivasi untuk terjaga sering kali dapat mendatangkan kantuk.

Dari uraian di atas dapat dipahami apabila kategori merokok pada responden tidak linier dengan gangguan pola tidur yang dialami, karena banyaknya faktor yang berkontribusi terjadinya gangguan tidur. Sedangkan pada penelitian ini faktor-faktor tersebut tidak diteliti. Akan tetapi yang perlu dicatat dan mendapatkan perhatian semua responden (100\%) adalah perokok dan $100 \%$ mengalami gangguan tidur.

\section{KESIMPULAN}

Berdasarkan penelitian ini didapatkan kesimpulan sebagai berikut: 
1. Karakteristik Responden: Mayoritas responden yaitu sejumlah 15 (50\%) dengan kategori perokok ringan, sedangkan 9 responden (30\%) dengan kategori perokok sedang, dan 6 responden $(20 \%)$ kategori perokok berat. Mayoritas responden dengan kategori gangguan tidur sedang, yaitu sejumlah 24 responden $(80 \%)$, sedangkan 4 responden (13.3\%) dengan kategori gangguan tidur ringan, dan 2 responden $(6.7 \%)$ dengan kategori gangguan tidur berat. Dari seluruh responden berjumlah 30 remaja $100 \%$ mengalami gangguan pola tidur.

2. Secara Statistik :

Diketahui hasil uji Pearson Chi-Square dimana $>$ dari $\alpha$ : 0.05 maka dapat disimpulkan bahwa tidak ada hubungan antara kategori merokok dengan kategori gangguan pola tidur. Atau kategori merokok tidak linier dengan kategori gangguan tidur.

\section{SARAN}

1. Bagi masyarakat secara umum dan khususnya orang tua yang memiliki anak usia remaja, agar memahami bahwa tidak terdapat hubungan antara kategori merokok dengan kategori gangguan tidur namun efek negatif dari rokok yang lain cukup banyak sehingga perlu kebijaksanaan dalam menyikapi kebiasaan merokok khususnya pada remaja

2. Bagi profesi perawat disarankan dapat memberikan anjuran kepada orang tua ataupun remaja secara langsung pada saat melakukan edukasi kepada masyarakat terkait dengan efek negatif dari merokok.

3. Bagi peneliti selanjutnya disarankan dapat menggunakan hasil penelitian ini sebagai data awal untuk melakukan penelitian selanjutnya yang lebih bervariatif.

\section{DAFTAR PUSTAKA}

Badan Penelitian dan Pengembangan Kesehatan Kementrian Kesehatan Republik Indonesia. 2013. Riset Kesehatan Dasar 2013. Kemenkes RI, Jakarta.

Caldwell, E. 2009. Berhenti Merokok. Alih bahasa Syafruddin Hasani dan Supriyanto Abdullah. PT LKiS Printing Cemerlang, Yogyakarta.

Husaini, A. 2006. Tobat Merokok. Alih bahasa At-Tadwhin Aduwwuka Aiiazi Tahwahu. Pustaka Iman, Jakarta.

Jaya, M. 2009. Pembunuh Berbahaya itu Bernama Rokok. Riz'ma, Sleman.

Kozier, B., G. Erb., A. Berman dan S.J. Snyder. 2010. Buku Ajar Fundamental Keperawatan: Konsep Proses dan Praktik. Alih bahasa Eko Karyuni, et al. EGC, Jakarta.

Mubarak, W.I., dan N. Chayatin. 2007. Kebutuhan Dasar Manusia. EGC, Jakarta.

Purnamasari, R.P. 2013. Faktor Faktor Penyabab Perilaku Merokok Pada Remaja. Universitas Pendidikan Indonesia. URL http://repository.upi.edu/2791 /9/S

PPB 0900772 Bibiliography. pdf, Diakses tanggal 11 November 2015.

Riset Kesehatan Dasar. Hasil Penelitian Riskesdas.

URL:http://ppnijateng.org/wpcounter/uploads/2014/9/8.hubungan-kebiasaan-me rokok-remaja-dengangangguan-pola-tidur.pdf, Diakses tanggal 10 November 2015. 
Widiansyah, M. 2014. Faktor Faktor Penyebab Perilaku Remaja Perokok di Desa Sidorejo Kabupaten Penajam Paser Utara. URL :http://ejournal.sos.fisipunmul.ac.id/site/wpcounten/uploads/2014/10/pe nting\%20(10-02-14-12-0455).pdf, Diakses tanggal 10 November 2015.

Vaora, M. 2014. Hubungan Kebiasaan Merokok Remaja dengan Gangguan Pola Tidur.

URL:http://ppnijateng.org/wpcounter/uploads/2014/9/8.hubungan-kebiasaan-me rokok-remaja-dengangangguan-pola-tidur.pdf, Diakses tanggal 10 November 2015.

${ }^{1}$ Dosen Akper Panti Kosala Surakarta ${ }^{2}$ Mahasiswa Akper Panti Kosala Surakarta 